IZA DP No. 1921

\title{
The Gender Wage Gap in Four Countries
}

Anne Daly

Akira Kawaguchi

Xin Meng

Karen Mumford

J anuary 2006 


\title{
The Gender Wage Gap in Four Countries
}

\author{
Anne Daly \\ University of Canberra \\ Akira Kawaguchi \\ Doshisha University \\ Xin Meng \\ Australian National University \\ and ERMES, University of Paris II \\ Karen Mumford \\ University of York, \\ National Institute for Labour Studies, Australia \\ and IZA Bonn
}

\section{Discussion Paper No. 1921 \\ January 2006}

\author{
IZA \\ P.O. Box 7240 \\ 53072 Bonn \\ Germany \\ Phone: +49-228-3894-0 \\ Fax: +49-228-3894-180 \\ Email: iza@iza.org
}

\begin{abstract}
Any opinions expressed here are those of the author(s) and not those of the institute. Research disseminated by IZA may include views on policy, but the institute itself takes no institutional policy positions.

The Institute for the Study of Labor (IZA) in Bonn is a local and virtual international research center and a place of communication between science, politics and business. IZA is an independent nonprofit company supported by Deutsche Post World Net. The center is associated with the University of Bonn and offers a stimulating research environment through its research networks, research support, and visitors and doctoral programs. IZA engages in (i) original and internationally competitive research in all fields of labor economics, (ii) development of policy concepts, and (iii) dissemination of research results and concepts to the interested public.
\end{abstract}

IZA Discussion Papers often represent preliminary work and are circulated to encourage discussion. Citation of such a paper should account for its provisional character. A revised version may be available directly from the author. 
IZA Discussion Paper No. 1921

January 2006

\section{ABSTRACT}

\section{The Gender Wage Gap in Four Countries*}

In a series of studies written during the 1980s Bob Gregory and his co-authors compared the gender wage gap in Australia with that found in other countries. They found it was not the difference in human capital endowments that explained different gender wage gaps but rather the rewards for these endowments. They concluded that country-specific factors, especially the institutional environment, were important in explaining the gender wage gap. This study updates Gregory's work by comparing the gender wage gap across four countries, Australia, France, Japan and Britain. Our results concord with those of Gregory: institutions are still important in explaining the relative size of the gender wage gap.

JEL Classification: J3, J7

Keywords: gender earnings, wage gap, institutions, workplace effects

Corresponding author:

Karen Mumford

Department of Economics and Related Studies

University of York

York YO10 5DD

United Kingdom

Email: kam9@york.ac.uk

\footnotetext{
*We thank the WERS98 sponsors - the Department of Trade and Industry, the Economic and Social Research Council, the Advisory, Conciliation and Arbitration Service and the Policy Studies Institute for allowing access to the WERS98 data. They are not responsible for any of the findings or claims made in the paper. Mumford is also grateful for financial support from the Leverhulme Foundation.
} 


\section{Introduction.}

In a series of papers written during the 1980s, Bob Gregory and his co-authors examined the gender wage gap in Australia and other countries, chiefly the United States (US) and Great Britain (Gregory and Duncan 1981, Gregory and Ho 1985, Gregory, Daly and Ho 1986, Gregory, Anstie, Daly and Ho 1989, Gregory and Daly 1991). ${ }^{1}$ These papers examined the removal of explicit pay discrimination against women and the promotion of equal pay in Australia in the late 1960s and early 1970s and compared the results with similar exercises in the US and Great Britain. The studies reveal a substantial narrowing of the gender wage gap in Australia and Great Britain over the 1970s but relatively little change in the US. Between 1969 and 1976 the ratio of female to male average weekly earnings for full-time workers rose 30 per cent in Australia and 20 per cent in Great Britain while there was no change in the US (Gregory, Anstie, Daly and Ho 1989).

Gregory argued that human capital differences alone could not explain the differing gender wage gaps in these countries. There was a significant role for the institutions of wage determination in bringing about these results. At the time Australia had a relatively centralised system of award-based wage setting that covered over 80 per cent of employees. In this environment decisions to promote equal pay for women were readily transmitted into increases in female pay. Britain also had a strong system of collective bargaining and strong trade unions that facilitated the introduction of equal pay. In contrast, the US had a highly decentralised system of pay determination and lower trade union density so the Equal Pay Act, 1963 and Title 7 of the Civil Rights Act, 1964 did not produce the changes in the gender wage gap observed in the other two countries. A key message of these studies was that institutions can be important in determining the size of the gender wage gap.

There have been major changes in the labour markets and institutions of wage determination in these countries over the past 30 years. The purpose of this paper is to once again examine the role of human capital and country-specific institutions in determining the gender wage gap. Using cross-sectional data from four countries, we consider whether the shift from a centralised system of wage determination in Australia to a more decentralised system where enterprise bargaining is important, appears to have negatively affected the gender wage gap. The countries chosen for this study, Australia, France, Japan and Britain, present a range of wage bargaining institutions. The choice of countries reflects the availability of establishment data and the research interests of the authors who are all graduates of the $\mathrm{PhD}$ programme at the Research School of Social Sciences ANU directed by Bob Grgeory.d In a study of collective bargaining structures in 1994, the OECD (1997) ranked France in the top half of centralised and coordinated systems and Australia and the United Kingdom as among the most decentralised and uncoordinated of systems in the OECD (see Table 1). The Japanese story was less clearcut, being ranked as highly coordinated and highly decentralised.

The paper is divided into the following sections. Part 2 outlines the institutions of wage determination in each of the countries. As the data used in subsequent sections of the

\footnotetext{
${ }^{1}$ More recent work by Bob Gregory in this area includes Gregory (1999).
} 
paper relate to the 1990s, the focus of this discussion will be the arrangements at that time. Part 3 describes the model that will be used to examine the gender wage gap in each country. Part 4 describes the data and Part 5 presents the results. Part 6 concludes with some discussion of these results.

\section{Institutions of Wage Determination.}

Each of the four countries (Australia, Britain, France and Japan) has explicit regulations designed to promote equal pay for women. In Australia, key decisions by the Commonwealth and State arbitration tribunals in the late 1960s and early 1970s promoted the concept of equal pay for women. ${ }^{2}$ This was subsequently formalised in legislation. The Equal Pay Act was passed in Britain in 1970 and included a broad concept of equity allowing for comparisons between jobs typically performed by women and jobs typically performed by men. French legislation in 1972 included a similar idea that was further formalised in legislation in 1983. This legislation set out the criteria (such as qualifications, working experience, and job description) that were to be used to compare jobs performed by men and women in determining work of equal value. In Japan equal pay legislation was introduced during the American occupation after the Second World War though this appears to have had a limited effect on the gender wage gap. In 1985 the Equal Employment Opportunity Law was enacted which prohibits gender discrimination in recruitment, assignment, promotion, retirement and dismissal. Additional clauses were added to the Law in 1997 to prevent sexual harassment and to promote positive action in favour of women.

These equal pay regulations have operated in different institutional environments in each of the countries. The Australian wage determination system of the 1990s had changed considerably from that described by Gregory and his co-authors for the 1970s. Under the later versions of the Prices and Incomes Accord between the Labor government and the Australian Council of Trade Unions (ACTU), there was a shift away from a centralised system of wage determination to one more closely focused on enterprise agreements. This change began in 1987 and has continued ever since, culminating in the current reforms proposed by the Howard government (Australian Financial Review 16th May 2005). As the system operated in the mid 1990s, there were minimum wage rates set through the Commonwealth and State award systems but there was scope for the negotiation of further wage increases at the enterprise level on the basis of productivity improvements and the introduction of more flexible work practices. The Industrial Relations Reform Act, 1993 introduced the possibility of direct bargaining between employers and employees without trade union involvement. Enterprise bargaining, mainly involving trade unions, spread rapidly over the period 1994 to 1996 (Wooden 2000, 2001) but the system of awards continued to play an important role in underpinning these agreements. Many of the enterprise agreements did not replace awards but complemented them and

\footnotetext{
${ }^{2}$ In 1969 the Commonwealth Conciliation and Arbitration Tribunal accepted the principle of equal pay for males and females undertaking the same work. In 1972 this was extended to equal pay for work of equal value, a wider concept and in 1974 a single minimum wage was introduced. The Sex Discrimination Act of 1986 and the Workplace Relations Act 1996 make it illegal to discriminate against someone on the basis of gender. For a recent perspective on these decisions see the Australian Economic Review (1999).
} 
were to be read in conjunction with the relevant award. Table 1 shows that Australia fell in the middle of OECD countries in the mid 1990s on measures of trade union density and collective bargaining coverage. At the time there was some concern that the changes to the system might prove disadvantageous to groups with limited industrial power, for example women and migrants (see Whitehouse (2001) for a discussion of some of these arguments).

Table 1: Collective Bargaining Characteristics of Selected Countries

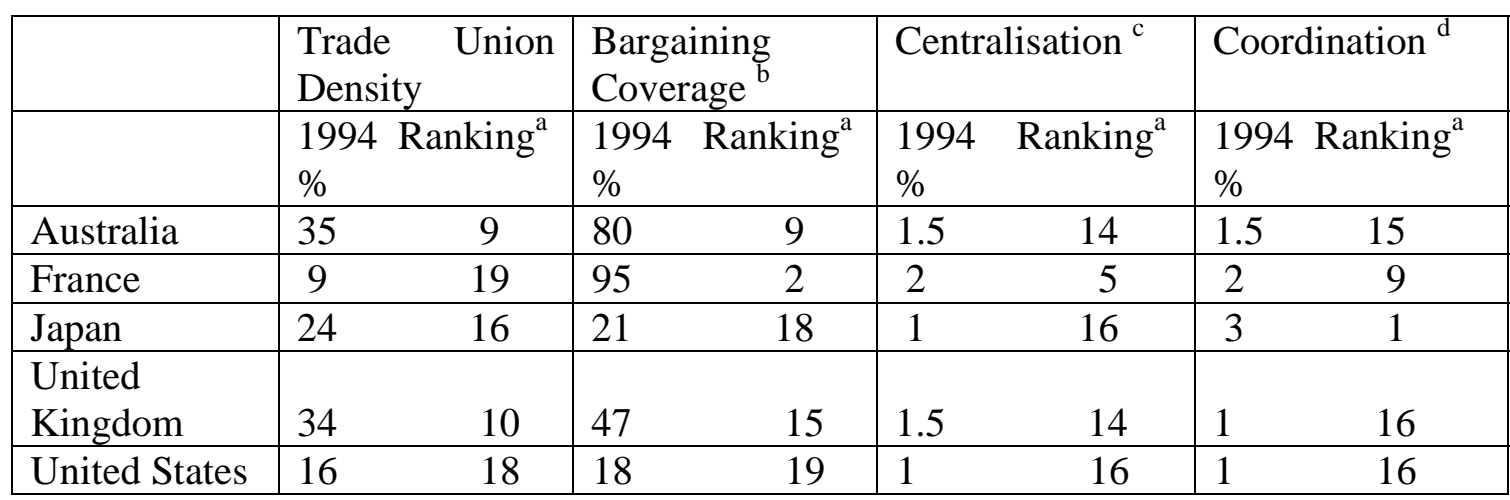

Source: OECD (1997)

Notes a. Ranking among the 19 OECD countries included in the study (Australia, Austria, Belgium, Canada, Denmark, Finland, France, Germany, Italy, Japan, Netherlands, New Zealand, Norway, Portugal, Spain, Sweden, Switzerland, United Kingdom, United States). The rankings go from most to least for each of the four indicators. The United States is included as a benchmark for a decentralised system.

b. The percentage of workers covered by collective agreements.

c. The locus of the formal structure for wage bargaining. The index takes a value of one for decentralised

systems and 3 for centralised systems.

d. Co-ordination measures the degree to which bargaining takes place on a similar basis across bargaining units even if it is not centrally organised. The index takes a value of 1 for uncoordinated systems and 3 for coordinated systems.

The French system of wage determination also combines both centralised and enterprise components (Meng and Meurs 2004, Ponthieux and Meurs 2005). There is a minimum wage set centrally and negotiations take place at the industry and enterprise level. Industry-level agreements between trade unions and employer federations establish compulsory industry minimum rates that apply to all union and non-union employees. The agreements at the enterprise level are important in setting actual pay rates above these minima. The system produces the surprising result reported in Table 1 of low union density accompanied by high coverage by collective agreements.

Japanese wage determination takes place at the enterprise level and the system was given the same rank on the centralisation index as the US, that is the most decentralised system among the 19 countries in the OECD study (see Table 1). There was however some coordination of bargaining strategies among members of employer organisations. As noted earlier, the Equal Employment Opportunity Law was enacted in 1985 and further 
amended in 1997 to prevent gender discrimination. However the law does not require the elimination of gender pay differences on the basis of the employees' classification within an organisation. Nearly half of the firms employing more than 5,000 employees have a two track employment system. The first, sogoshoku, or management career track, is for employees in management positions who are expected to move around the country as required. The second, ippanshoku, or general track, is for lower skilled workers who are not required to be mobile and are not expected to join the ranks of company management. Women are more likely to be found on this second track. During the 1990s the seniority system has declined in importance and a more results-based wage system has been introduced. As the seniority system favoured men over women, this change is likely to have helped reduce the gender wage gap.

The British system of wage determination, like the Australian system, has become dramatically decentralised since the late 1970s with the introduction of labour market reforms by the Thatcher Conservative government. This process of deregulatory reforms was continued by subsequent governments so effectively that by 2000 the United Kingdom was considered to be one of the most market friendly OECD countries (Card, Blundell and Freeman, 2004:1). Trade union density has fallen substantially and the percentage of the workforce covered by a collective agreement has declined to under half compared with 70 per cent in 1980 (OECD 1997, Grainger and Holt 2005; 1). The data to be used for Britain were collected in 1998; after the industry based Wage Councils were abolished in August 1993 and before the national minimum wage was introduced in April 1999 (Gosling and Lemieux, 2004).

Figure 1 shows the ratio of female to male earnings in the four countries over the 1990s. In Australia, Britain and France there has been a slight increase in the ratio over the 1990s but in Japan, there has been a significant growth. Kawaguchi's (2004) comparison of decomposition results for Japan in 1990 and 2000 finds that changes in the endowments and rewards for experience with the current employer are important in explaining the reduction of the gender wage gap in Japan over this period. First impressions of the Australian data do not suggest a deterioration in the gender wage gap over the 1990s as the arbitration system became less important in determining pay rates. This study does not, however, seek to explain changes in the gender wage gap over time but rather focuses on a cross-country comparison based on surveys conducted in the 1990s. The data we use will be discussed below. 


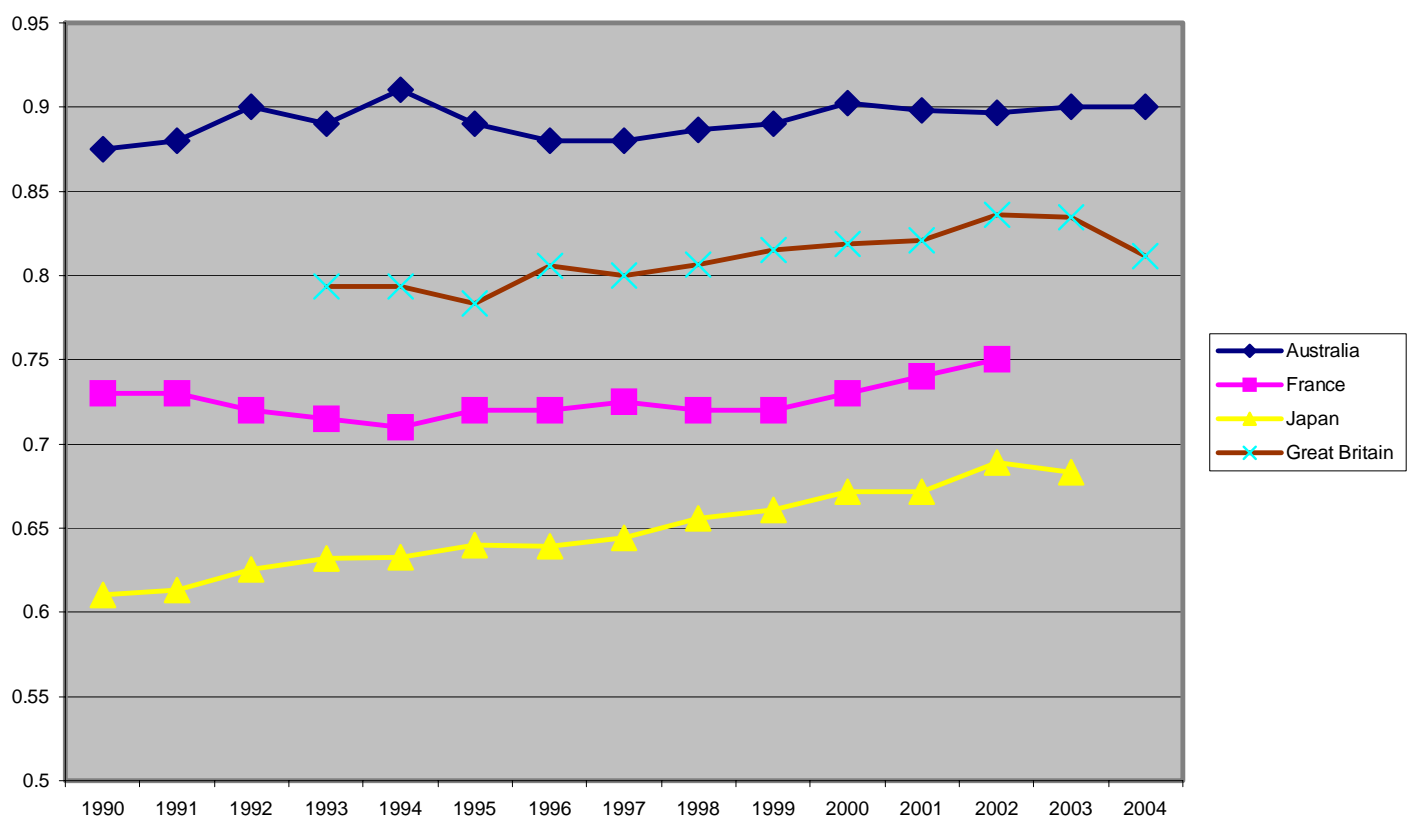

Note: The gender wage gap is measured by the hourly rate for full-time non-managerial employees in Australia, the median monthly income for those working more than 10 hours in France, the income for fulltime employees excluding bonuses in Japan and gross hourly earnings of full-time employees in Britain.

\section{The Model.}

There is an enormous literature examining the gender wage differential in the context of the human capital model developed by Becker (1975) and Mincer (1974). Using semilogarithmic wage equations, we estimate the earnings equation as:

$$
Y_{i}=\alpha+X_{i} \beta+\varepsilon_{i}
$$

where $\mathrm{Y}_{i}$ is the natural $\log$ of the wage for individual $i ; \alpha$ is an intercept term; $X_{i}$ is a vector of regressors capturing the individual characteristics expected to impact on wages; and $\varepsilon_{i}$ is a residual term.

The linked nature of our datasets can be used to good effect to incorporate workplace information into the analysis of individual wages. This may be important where women's earnings relative to men's reflect differences in workplace practices of pay determination. We can allow for workplace specific fixed effects where the model to be estimated is:

$$
Y_{i}=\alpha+X_{i k} \beta+\gamma_{k}+\varepsilon_{i}
$$

where $k$ represents the workplace and $\gamma_{k}$ the workplace specific effect. 
The gender wage differential can then be decomposed into that part attributable to differences in human capital endowments (the $X \mathrm{~s}$ ) and that part attributable to the rewards for those endowments (the $\beta$ s) (Oaxaca 1973, see Blau and Kahn 1997 and Altonji and Blank 1999 for recent surveys). The allocation of the gap between endowments, and their rewards will depend on the choice of coefficients used for the decomposition ( $\beta_{m}$ or $\beta_{f}$ where $\mathrm{m}$ and $\mathrm{f}$ indicate male and female respectively).

$$
\bar{Y}_{m}-\bar{Y}_{f}=\left(\bar{X}_{m}-\bar{X}_{f}\right) \hat{\beta}_{m}+\bar{X}_{f}\left(\hat{\beta}_{m}-\hat{\beta}_{f}\right)
$$

This methodology is modified in the present study to focus on explanations of the gender wage gap between the four countries. Using Australia (a) as the benchmark country for purposes of illustration, the following decompositions have been calculated for males and females for each of the countries $(j=1 \ldots 3)$ compared with Australia $(a)$ :

$$
\begin{aligned}
& \bar{Y}_{f a}-\bar{Y}_{f j}=\left(\bar{X}_{f a}-\bar{X}_{f j}\right) \hat{\beta}_{a}+\bar{X}_{f j}\left(\hat{\beta}_{f a}-\hat{\beta}_{f j}\right) \\
& \bar{Y}_{m a}-\bar{Y}_{m j}=\left(\bar{X}_{m a}-\bar{X}_{m j}\right) \hat{\beta}_{a}+\bar{X}_{m j}\left(\hat{\beta}_{m a}-\hat{\beta}_{m j}\right)
\end{aligned}
$$

The first term in each equation measures the average differences in human capital endowments between males or females in the two countries. The second term measures the difference in the rewards for these endowments. Combining the results from these two equations indicates how much of the difference in the gender wage gap between the two countries is explained by the relative human capital endowments of males and females in each country and how much by differences in the rewards for these endowments.

\section{The Data.}

Gregory and his co-authors found that the gender pay gap in Australia was relatively small compared with other countries in the 1980s and this paper examines whether this relative position changed in the 1990s. In each of the four countries, there was a survey of workplaces at this time that also collected linked information on individual employees. Whilst these data sets have striking similarities, they are unfortunately not identical. Due to the need to have comparable samples in the four countries, we have restricted the sample to full-time employees (working at least 30 hours per week) ${ }^{3}$ in establishments with 20 or more employees. ${ }^{4}$ Mining and public administration have been excluded. Brief variable definitions and sample statistics are presented in Table 2 (and in the Appendix, available upon request) and Table 2 and will be discussed below.

Data for Australia are taken from the Australian Workplace Industrial Relations Survey (AWIRS95) which is the second in a series of large-scale surveys of workplaces in

\footnotetext{
${ }^{3}$ Comparable data on part time employment are not available for Japan.

${ }^{4}$ The Japanese sample includes firms with more than 10 employees.
} 
Australia (the first survey, AWIRS90, was carried out in 1990). Both AWIRS surveys were undertaken by what is now the Australian Department of Employment and Workplace Relations. Surveying for AWIRS95 was conducted between August 1995 and January 1996. The respondents were taken from 2001 workplaces, all of which employed 20 or more employees. From each of these workplaces, the general manager, the employee relations manager and trade union delegate (from the union with most members at the workplace) were asked to complete separate face-to-face surveys. The results from each of these three surveys are fully linkable. Furthermore, individual employees from these workplaces were also surveyed for a range of information including their personal characteristics, individual job characteristics, work environment, etc. This survey of individual employees included 19,155 employees. Of the workplaces considered in the main AWIRS95 surveys, 2001 returned at least one of the three surveys. We encounter some missing values (apparently randomly distributed) across the variables, and exclude those not working full-time, so that 1,580 workplaces and 13,082 employees are included in our regression analysis.

The French data are from the 1992 French Labour Cost and Wage Structure Survey which was conducted in 1993 by the French National Statistics Institute (INSEE). The survey was conducted among non-agricultural private firms and had questionnaires covering each establishment and a randomly selected sample of individual employees. Results were available for about 15,000 establishments and 146,000 employees.

Data for Japan are taken from the Basic Survey of Wage Structure in 1990 conducted by the Ministry of Labor. This survey covers employees in private enterprises with 5 or more employees and in some public enterprises with 10 or more employees. Information was collected on the firms and on individuals working in those firms.

The data used in this study for Britain are drawn from the British Workplace Employee Relations Survey 1998 (WERS98) (Department of Trade and Industry 1999). WERS98 is a nationally representative survey of workplaces with 10 or more employees containing a vast amount of information. Face-to-face interviews for WERS98 were conducted with a

Table 2: Average Values of Variables used in the Regression Analysis.

\begin{tabular}{|l|c|c|c|c|}
\hline & Males & & & \\
\hline & Australia & France & Japan & Britain \\
\hline Hourly pay & \$A15.30 & FR78.88 & Yen('000)2.03 & £8.01 \\
\hline Ln hourly pay & 2.66 & 4.26 & 0.61 & 1.95 \\
\hline Pot. Exp. outside current firm & 13.31 & 12.10 & 8.30 & 18.42 \\
\hline Tenure with current firm & 7.01 & 11.94 & 12.61 & 5.93 \\
\hline Education & & & & \\
\hline Incomplete Secondary School & 0.31 & 0.67 & 0.15 & 0.65 \\
\hline Complete Secondary School & 0.46 & 0.16 & 0.51 & 0.13 \\
\hline Post secondary school & 0.23 & 0.16 & 0.34 & 0.22 \\
\hline Establishment size & & & & \\
\hline Work size <30 & 0.07 & 0.29 & 0.14 & 0.06 \\
\hline Work size 30-99 & 0.40 & 0.18 & 0.20 & 0.26 \\
\hline
\end{tabular}




\begin{tabular}{|l|c|c|c|c|} 
Work size 100-299 & 0.27 & 0.10 & 0.18 & 0.27 \\
\hline Work size 300-499 & 0.10 & 0.15 & 0.07 & 0.12 \\
\hline Work size 500-999 & 0.08 & 0.14 & 0.08 & 0.12 \\
\hline Work size 1000+ & 0.08 & 0.13 & 0.32 & 0.16 \\
\hline Industry & & & & \\
\hline Manufacturing & 0.33 & 0.32 & 0.36 & 0.43 \\
\hline Electricity,gas,water & 0.03 & 0.05 & 0.01 & 0.01 \\
\hline Construction & 0.04 & 0.07 & 0.10 & 0.06 \\
\hline Wholesale+retail & 0.13 & 0.08 & 0.16 & 0.11 \\
\hline Trans, storage, communication & 0.09 & 0.21 & 0.13 & 0.11 \\
\hline Finance & 0.04 & 0.05 & 0.04 & 0.04 \\
\hline Property and business & 0.09 & 0.02 & 0.01 & 0.09 \\
\hline Other services & 0.25 & 0.21 & 0.18 & 0.13 \\
\hline & & & & \\
\hline & Females & & & \\
\hline Hourly pay & $\$ A 13.74$ & FR62.62 & YEN ('000)1.293 & $£ 6.72$ \\
\hline Hourly pay ratio f/m & 0.90 & 0.79 & 0.64 & 0.84 \\
\hline Ln hourly pay & 2.56 & 4.07 & 0.17 & 1.78 \\
\hline Pot. Exp. outside current firm & 12.95 & 11.20 & 10.14 & 16.63 \\
\hline Tenure with current firm & 5.49 & 11.32 & 7.45 & 5.30 \\
\hline Education & & & & \\
\hline Incomplete Secondary School & 0.31 & 0.55 & 0.13 & 0.59 \\
\hline Complete Secondary School & 0.38 & 0.26 & 0.56 & 0.14 \\
\hline Post secondary school & 0.31 & 0.19 & 0.32 & 0.27 \\
\hline Establishment size & & & & \\
\hline Work size <30 & 0.08 & 0.31 & 0.15 & 0.09 \\
\hline Work size 30-99 & 0.39 & 0.19 & 0.22 & 0.29 \\
\hline Work size 100-299 & 0.26 & 0.10 & 0.22 & 0.26 \\
\hline Work size 300-499 & 0.08 & 0.13 & 0.07 & 0.10 \\
\hline Work size 500-999 & 0.08 & 0.13 & 0.08 & 0.09 \\
\hline Work size 1000+ & 0.12 & 0.15 & 0.25 & 0.17 \\
\hline Industry & & & & \\
\hline Manufacturing & 0.14 & 0.25 & 0.31 & 0.23 \\
\hline Electricity,gas,water & 0.01 & 0.02 & 0.00 & 0.01 \\
\hline Construction & 0.00 & 0.01 & 0.04 & 0.01 \\
\hline Wholesale+retail & 0.13 & 0.10 & 0.18 & 0.11 \\
\hline Trans, storage, communication & 0.04 & 0.06 & 0.04 & 0.04 \\
\hline Finance & 0.08 & 0.09 & 0.09 & 0.07 \\
\hline Property and business & 0.09 & 0.02 & 0.01 & 0.11 \\
\hline Other services & 0.45 & 0.33 & 0.38 \\
\hline Source: Das collected via & & & \\
\hline
\end{tabular}

Source: Data collected via establishments in each country.

manager (with day-to-day responsibility for employee relations) at 2,191 workplaces between October 1997 and June 1998. Furthermore, at each of 1,880 of these workplaces, a questionnaire was presented to 25 randomly selected employees (in workplaces with more than 25 employees) or to all the employees (in workplaces with 
fewer than 26 employees), resulting in over 28,000 completed employee questionnaires. The response rates were $80 \%$ for the face-to-face management and worker representative interviews and nearly $65 \%$ for the employee questionnaire. WERS98 is a stratified random sample, and larger workplaces and some industries are over-represented. Retaining only those individuals who have complete information for the variables used in the analyses below leaves 17,533 individuals from 1,449 workplaces. The data have been weighted throughout the paper, where possible, to allow for the complex survey design (Deaton, 1998) and thus represent the sampling population.

Table 2 presents summary statistics for each of the countries. The first important result is that for this sample of full-time employees, the gender wage gap was smallest in Australia. The average Australian woman earned 90 per cent of the average Australian male earnings. This compared with 79 per cent in France, 64 per cent in Japan and 84 per cent in Britain. At first approximations it does not appear that Australian women have lost the gains made in the 1970s in relative pay.

The remainder of the table presents summary statistics for males and females. Whilst most of these measures are self explanatory, we do incorporate two measures of working experience in our analysis; tenure with the current employer and potential experience in other employment (age minus years of schooling minus current job tenure). This second measure has the familiar limitation because it assumes an individual will be in employment from the time of leaving the education system to the age at the time of the survey. This is perhaps an extreme assumption, especially for women who frequently take time out of the labour force during their childbearing years. We could accordingly expect our measure of endowments to be biased upwards for women (suggesting they have more work experience than they actually do). This may lead us to conclude that the unexplained gender gap is subsequently higher. We do not have data on actual labour market experience needed to measure experience more accurately. We will, however, return to discuss this potential source of bias below.

Tenure with current employer was longer for males than females. It was particularly long for French and Japanese males while potential experience outside the current firm was longest for British males (Mumford and Smith, 2004). Among females, tenure was longest for the French. The largest differences between males and females were for Japan. Japanese males actually had lower potential experience than Japanese females but they had 5.16 more years of tenure with their current employer. This striking difference in potential experience and tenure for Japan may be because men are less likely to change employees than females, but is more likely due to Japanese women leaving the labour market when rearing children. This suggests the need to be aware of possible bias when using our measure of potential experience is particularly relevant for Japan.

\section{Results.}

Table 3 presents the regression results for males and females using OLS (similar tables of results for the workplace-specific fixed effects models are included in the Appendix, 
available upon request). The overall test of the explanatory power of the regressors is clearly significant for all the regressions and whilst the $\mathrm{R}^{2}$ measures are not high, they are comparable with those found in other studies using cross sectional data. Overall, the parameter estimates are generally well defined and have the expected sign.

The OLS regressions include as explanatory variables individual characteristics (educational qualifications, tenure with the current firm and potential experience outside the firm) and workplace characteristics (size of establishment and industry of employment). We have also included regional dummies for place of residence as control variables (not reported in the decompositions below).

These results show males in France and Britain gained the largest addition to their hourly earnings rate from post secondary qualifications compared with males who had not completed secondary school. Males in each country received a larger premium for these qualifications than females in the same country. For both males and females, firm size had the largest effect on the hourly earnings rate in Japan and Britain with a relatively small effect in Australia. Males and females working in larger workplaces had higher hourly pay rates than those in smaller establishments. Relative to the omitted industry of construction, hourly earnings were lower in manufacturing, wholesale and retail trade and other services for both males and females in Australia. Manufacturing also had relatively low hourly earnings rates in Japan and Britain for males and for females in all the countries. Retail and wholesale trade was another industry with consistently lower hourly wage rates than in construction (the exception was for males in France).

As described above, we included two measures of experience in the regression analyses; tenure with the current employer and potential experience in the workforce. The returns to tenure were largest for males in all four countries. In Australia, Japan and France, the returns to tenure were also larger than for potential experience for males. This was not the case in Britain where the gains from an extra year of potential experience exceeded that for tenure for both males and females. These estimates may reflect differences in the way the labour markets operate in these countries. In Japan, the rewards are directed towards those who continue to work for the same employer while at the other extreme in Britain, the greater rewards go to those who switch employers. For females the returns to tenure and potential experience were similar in Australia but were larger in France and Japan. As discussed above, however, the returns to potential experience may be biased due to women leaving the labour market during the childbearing years implying that potential experience may not reflect actual working experience. 
Table 3: OLS regression results.

\begin{tabular}{|c|c|c|c|c|c|c|}
\hline & \multicolumn{4}{|c|}{ Females } & \multicolumn{2}{|l|}{ Males } \\
\hline & Australia & France & Japan & Britain & Australia France & Jap \\
\hline \multicolumn{7}{|l|}{ Dependent Variable $=$} \\
\hline Ln Hourly Earnings & 2.56 & 4.07 & 0.17 & 1.78 & 2.66 & \\
\hline Constant & 2.1781 & 3.9299 & -0.4162 & 1.0296 & $2.1878 \quad 3.8143$ & \\
\hline \multirow[t]{2}{*}{ Potential experience outside current firm } & 0.0201 & 0.0066 & 0.0056 & 0.0315 & $41.46^{\star \star} 415.43^{\star \star}$ & -4 \\
\hline & $11.36^{\star \star}$ & $11.16^{* *}$ & $201.75^{\star \star}$ & $14.94^{\star \star}$ & $0.0193 \quad 0.0125$ & \\
\hline \multirow{2}{*}{ Potential experience $^{2}$} & -0.0004 & -0.0002 & -0.0002 & -0.0008 & $12.82^{\star \star} 22.65^{\star \star}$ & * 11 \\
\hline & $-8.56^{\star *}$ & $-9.09 * *$ & $-213.35^{\star \star}$ & $-12.76^{\star \star}$ & $-0.0004-0.0002$ & \\
\hline \multirow[t]{2}{*}{ Tenure with current firm } & 0.0192 & 0.0193 & 0.0282 & 0.0662 & $-9.37^{\star \star} \quad-12.2^{\star \star}$ & -8 \\
\hline & $7.79 * \star$ & $32.23^{* *}$ & $736.86^{* *}$ & $6.81 * *$ & 0.026 & \\
\hline \multirow[t]{2}{*}{ Tenure $^{2}$} & -0.0004 & -0.0002 & -0.0002 & -0.004 & $13.32^{\star \star} \quad 42.48^{\star \star}$ & 16 \\
\hline & $-3.82^{\star \star}$ & $-8.88^{\star *}$ & $-180.99 * \star$ & $-4.48^{* \star}$ & $-0.0005-0.0002$ & \\
\hline \multirow[t]{2}{*}{ CompletedSecondary School } & 0.1357 & 0.1213 & 0.1553 & 0.2342 & $-8.01^{\star \star}-12.62^{\star \star}$ & -5 \\
\hline & $10.79 \star \star$ & $29.44^{\star *}$ & $434.76^{\star \star}$ & $12.71^{* *}$ & $\begin{array}{ll}0.1828 & 0.1967 \\
\end{array}$ & \\
\hline \multirow[t]{2}{*}{ Post secondary school } & 0.3767 & 0.4539 & 0.3023 & 0.5492 & $14.63^{\star \star} \quad 45.43^{\star \star}$ & 7 \\
\hline & $24.17^{\star \star}$ & $93.26 * *$ & $710.44^{\star \star}$ & $23.37 * *$ & $0.413 \quad 0.6406$ & \\
\hline \multirow[t]{2}{*}{ Workforce size 30-99 } & 0.0138 & -0.0068 & 0.0501 & 0.0378 & $22.45^{\star \star} 139.01^{\star *}$ & 14 \\
\hline & 0.57 & -1.3 & $149.85^{\star \star}$ & 0.86 & $-0.0277-0.0003$ & \\
\hline \multirow[t]{2}{*}{ Workforce size 100-299 } & 0.012 & 0.0092 & 0.0962 & 0.0634 & -1.15 & \\
\hline & 0.46 & 1.57 & $285.27^{\star \star}$ & 1.39 & $\begin{array}{ll}-0.0017 & 0.0232 \\
\end{array}$ & \\
\hline \multirow[t]{2}{*}{ Workforce size 300-499 } & 0.0917 & 0.0547 & 0.1377 & 0.134 & -0.07 & 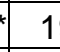 \\
\hline & $3.06 * *$ & 7.88 & $298.77^{\star \star}$ & 2.66 & $0.0469 \quad 0.0947$ & \\
\hline \multirow[t]{2}{*}{ Workforce size 500-999 } & 0.0648 & 0.0703 & 0.1611 & 0.1509 & $1.4414 .17^{\star \star *}$ & t 2 \\
\hline & $2.21^{*}$ & $10.87^{* *}$ & $359.39 * *$ & $2.91 * \star$ & $0.0474 \quad 0.0758$ & \\
\hline \multirow[t]{2}{*}{ Workforce size $1000+$} & 0.1476 & 0.0606 & 0.2269 & 0.2464 & $1.512 .54^{\star \star}$ & * 3 \\
\hline & $5.34^{\star \star}$ & $9.26 * \star$ & $629.81^{\star \star}$ & $4.55^{\star *}$ & $0.0897 \quad 0.0618$ & \\
\hline \multirow[t]{2}{*}{ Manufacturing } & -0.1505 & -0.063 & -0.1153 & -0.0297 & $2.94^{\star *}$ & 8 \\
\hline & $-3.9^{* *}$ & $-3.66^{\star *}$ & $211.78^{\star *}$ & $\begin{array}{ll}-0.63 \\
\end{array}$ & $\begin{array}{ll}-0.0394 & 0.1127\end{array}$ & \\
\hline \multirow[t]{2}{*}{ Electricity,gas,water } & 0.078 & 0.0871 & 0.1403 & 0.1949 & $17.3^{\star \star}$ & -3 \\
\hline & 1.69 & $4.23^{* *}$ & $79.85^{\star \star}$ & $3.94 * *$ & $0.0657 \quad 0.2532$ & \\
\hline \multirow[t]{2}{*}{ Wholesale+retail } & -0.159 & -0.0856 & -0.0195 & -0.0924 & $2.11^{*} 27.41^{\star *}$ & 1 \\
\hline & $-3.99 * *$ & $-4.87^{\star \star}$ & $-34.47^{\star *}$ & $-2.01 *$ & -0.0802 & \\
\hline \multirow[t]{2}{*}{ Trans, storage, communication } & -0.0198 & 0.0519 & 0.0467 & 0.061 & $-2.92^{\star \star}$ & -3 \\
\hline & -0.44 & $2.85^{\star *}$ & $63.86^{\star *}$ & 1.16 & $0.0116 \quad 0.1163$ & \\
\hline \multirow[t]{2}{*}{ Finance } & 0.0191 & 0.1224 & 0.0735 & 0.1387 & $0.37 \quad 17.24^{\star \star}$ & -2 \\
\hline & 0.48 & $6.9^{* *}$ & $116.09 * 9_{-}$ & $2.98 * *$ & $0.1111 \quad 0.2688$ & \\
\hline \multirow[t]{2}{*}{ Property and business } & 0.0113 & -0.0944 & 0.0551 & 0.1153 & $3.83^{\star *} \quad 28.92^{* \star}$ & * 2 \\
\hline & 0.26 & $-4.68^{\star *}$ & $37.78^{\star \star}$ & $2.32^{*}$ & $0.0477 \quad-0.0511$ & \\
\hline \multirow{2}{*}{ Other services } & -0.1186 & -0.0349 & 0.1264 & -0.0837 & $-3.72^{\star \star}$ & \\
\hline & $-3.12^{\star \star}$ & $-2.05^{\star}$ & $233.51^{\star \star}$ & $-1.96 *$ & $-0.0533 \quad 0.0711$ & \\
\hline \multirow[t]{2}{*}{ Regional controls } & Yes & Yes & Yes & Yes & $-1.8 \quad 10.65^{\star \star}$ & * -1 \\
\hline & & & & & Yes & $\mathrm{Ye}$ \\
\hline Observations & 5172 & 26125 & 7875186 & 7162 & 46967 & 17 \\
\hline
\end{tabular}


Note: The omitted categories are those with incomplete secondary education, employed in a firm with less than 30 employees and in construction. In each country a region has been omitted but these are not easily compared across countries. 't'statistics are presented in brackets. * indicates the coefficient was significant at the $5 \%$ level and ** at the $1 \%$ level. 
The full set of results for the model with workplace specific fixed effects are presented in the Appendix (available upon request). As enterprise bargaining will take place at this level, this allows us to consider the impact of workplace specific effects through bargaining or other processes on the gender wage gap (see also Mumford and Smith 2003, Meng and Meurs 2004). Thus we will allow for both individual characteristics and workplace fixed effects, enabling us to concentrate more specifically on national differences in the gender gaps.

The results including workplace fixed effects are similar to those for the OLS regressions and show positive returns for education, tenure and potential experience. The rewards for tenure with the current firm were in general greater than for potential experience outside the firm. The British results again did not conform with this general trend for returns to the two types of experience. The returns to education were in general reduced once workplace-specific effects were included in the model. This suggests that the more educated workers were concentrated in the workplaces that were in general high paying workplaces.

Tables 4-7 present the results of the decompositions using equations (4) and (5). Table 4 reports the estimated gender wage gap in each of the four countries based on the OLS regression results (see Table 3 ). The ratios on the diagonal show the estimated gap in each country using the average endowments of males and females in that country multiplied by the estimated regression coefficients. The smallest gap in the hourly wage rate is found in Australia where the average female working more than 30 hours per week had a predicted hourly wage rate of 93 per cent of the average male. The ratio was similar for Britain and France where the average female working full-time earned 82 and 83 per cent respectively of the hourly wage rate of the average male. The gap was, however, much larger in Japan. Japanese females working full-time earned only 64 per cent of Japanese males earnings on an hourly basis.

The off-diagonal ratios in Table 4 show the estimated gender wage gap given the human capital endowments in each country listed in the first column assuming both males and females were paid according to the coefficients from each of the other countries in turn. For example, the first row shows that the ratio of female to male hourly earnings in Australia was 0.93. If Australian full-time workers were paid according to the Japanese estimated coefficients, the ratio would have been 0.72 and there would have been a much larger gender wage gap of $0.28 .^{5}$ Similarly, if Australians were paid according to French coefficients, the gender wage gap would also have been larger at 0.24 . The gender wage gap would have been smaller, however, if Australians were paid according to the British coefficients. In general, the gender wage gap was largest when the Japanese coefficients were used (Table 3 column 3). The surprising result that Japanese women would be paid more than Japanese men if rewarded according to the British coefficients arises because according to our estimates, there are low or negative rewards for long tenure in Britain

\footnotetext{
${ }^{5}$ The off-diagonal ratios are calculated by taking the average measured endowments of males and females in the countries listed vertically and multiplying them by the coefficients from the regressions estimated for the countries listed horizontally.
} 
and greater rewards for potential experience. Japanese men have relatively long tenure and Japanese women relatively long potential experience.

Table 5 breaks the gender wage gap into two components: the portion that can be explained by differences in the relative human capital endowments between males and females across the countries; and the portion that can be explained by differences in the rewards for these endowments between the countries. The first half of the table presents the breakdown using Australian coefficients. The results here are clear; by far the most important determinant of differences in the gender wage gap between these countries and Australia are a result of differences in the rewards for human capital endowments in these countries. Human capital endowments play a role but they are not the major source of differences.

Table 4: The Gender Pay Gap using the OLS Model, Australia, France, Britain and Japan

\begin{tabular}{|l|l|c|c|c|c|}
\hline & & Coefficients & & & \\
\hline & & $\begin{array}{c}\text { Australia } \\
(1)\end{array}$ & $\begin{array}{c}\text { Britain } \\
(2)\end{array}$ & $\begin{array}{c}\text { Japan } \\
(3)\end{array}$ & $\begin{array}{c}\text { France } \\
(4)\end{array}$ \\
\hline Endowments & Australia & 0.93 & 0.94 & 0.72 & 0.76 \\
\hline & Britain & 0.94 & 0.82 & 0.70 & 0.81 \\
\hline & Japan & 0.86 & 1.09 & 0.64 & 0.74 \\
\hline & France & 0.90 & 0.74 & 0.71 & 0.83 \\
\hline
\end{tabular}

Table 5: Explaining the Gender Wage Gap between Australia and Each of the Other Countries, OLS Model.

\begin{tabular}{|c|c|c|c|}
\hline & $\begin{array}{l}\text { Using Australian } \\
\text { coefficients }\end{array}$ & & \\
\hline & Endowments & Coefficients & Total Gap \\
\hline Aust/Japan & $\begin{array}{c}0.07 \\
(37 \%)\end{array}$ & $\begin{array}{c}0.12 \\
(63 \%) \\
\end{array}$ & $\begin{array}{c}0.19 \\
(100 \%) \\
\end{array}$ \\
\hline Aust/ Britain & $\begin{array}{l}-0.01 \\
(-9 \%)\end{array}$ & $\begin{array}{c}0.12 \\
(109 \%)\end{array}$ & $\begin{array}{c}0.11 \\
(100 \%)\end{array}$ \\
\hline \multirow[t]{3}{*}{ Aust/France } & $\begin{array}{c}0.03 \\
(30 \%)\end{array}$ & $\begin{array}{c}0.07 \\
(70 \%)\end{array}$ & $\begin{array}{c}0.10 \\
(100 \%)\end{array}$ \\
\hline & $\begin{array}{l}\text { Using Other } \\
\text { Country } \\
\text { Coefficients }\end{array}$ & & \\
\hline & Endowments & Coefficients & Total Gap \\
\hline Aust/Japan & $\begin{array}{l}-0.02 \\
(-5 \%)\end{array}$ & $\begin{array}{c}0.21 \\
(105 \%) \\
\end{array}$ & $\begin{array}{c}0.19 \\
(100 \%) \\
\end{array}$ \\
\hline Aust/ Britain & $\begin{array}{c}0.12 \\
(109 \%) \\
\end{array}$ & $\begin{array}{l}-0.01 \\
(-9 \%)\end{array}$ & $\begin{array}{c}0.11 \\
(100 \%) \\
\end{array}$ \\
\hline Aust/France & -0.07 & 0.17 & 0.10 \\
\hline
\end{tabular}




\begin{tabular}{|l|l|l|l|}
\hline & $(-70 \%)$ & $(170 \%)$ & $(100 \%)$ \\
\hline
\end{tabular}

These results are sensitive to the choice of base country used. The second section of the table presents the decomposition using the second country's coefficients. Coefficients remain the main source of the difference in the gender wage gap between Australia and that found in Japan and France but endowments were more important in the Australia/Britain comparison. The Australian gender wage gap would have been smaller at 6 per cent if Australians were rewarded for human capital endowments according to the British coefficients. This was 12 percentage points smaller than the British gender wage gap (see Table 4). An average of these estimates based on the two sets of coefficients confirms the importance of differences in the rewards for human capital endowments in explaining the differences in the gender wage gap between the countries.

Tables 6 and 7 report the results using workplace specific fixed effects. The results are similar to those reported above using the OLS equations but, as discussed above, allowing for the workplace fixed effects slightly lowers the returns to educational endowments. The smallest gender wage gap was again in Australia and the largest in Japan. The gender wage gap would have increased most if males and females in Australia, Britain and France were paid according to the Japanese coefficients. The major difference in results between Tables 3 and 5 occurs in the gap for Japanese endowments with French coefficients. This gap changes from 0.26 to 0.05 when workplace specific effects are allowed for. This is predominantly due to the fall in returns to education for French men estimated in the fixed effects model.

Table 7 supports the findings in Table 5 that most of the difference in the gender wage gap can be explained by coefficients rather than by differences in human capital endowments. The one exception was in comparing Australia and Britain using British coefficients. In this case endowment differences explained all of the gap. In the case of comparisons between Australia/Japan and Australia/France, the importance of the coefficients was reduced using the fixed effects model although they still remained the major source of difference.

Table 6: The Gender Pay Gap using the Fixed Effects Model, Australia, France, Britain and Japan

\begin{tabular}{|l|l|c|c|c|c|}
\hline & & Coefficients & & & \\
\hline & & $\begin{array}{c}\text { Australia } \\
(1)\end{array}$ & $\begin{array}{c}\text { Britain } \\
(2)\end{array}$ & $\begin{array}{c}\text { Japan } \\
(3)\end{array}$ & $\begin{array}{c}\text { France } \\
(4)\end{array}$ \\
\hline Endowments & Australia & 0.89 & 0.89 & 0.69 & 0.80 \\
\hline & Britain & 0.89 & 0.81 & 0.68 & 0.81 \\
\hline & Japan & 0.86 & 1.04 & 0.64 & 0.95 \\
\hline & France & 0.89 & 0.89 & 0.70 & 0.82 \\
\hline
\end{tabular}


Table 7: Explaining the Gender Wage Gap between Australia and Each of the Other Countries, Fixed Effects Model.

\begin{tabular}{|c|c|c|c|}
\hline & $\begin{array}{l}\text { Using Australian } \\
\text { coefficients }\end{array}$ & & \\
\hline & Endowments & Coefficients & Total Gap \\
\hline Aust/Japan & $\begin{array}{c}0.03 \\
(12 \%)\end{array}$ & $\begin{array}{c}0.22 \\
(88 \%)\end{array}$ & $\begin{array}{c}0.25 \\
(100 \%)\end{array}$ \\
\hline Aust/ Britain & $\begin{array}{l}0.00 \\
(0 \%)\end{array}$ & $\begin{array}{c}0.08 \\
(100 \%)\end{array}$ & $\begin{array}{c}0.08 \\
(100 \%)\end{array}$ \\
\hline \multirow[t]{3}{*}{ Aust/France } & $\begin{array}{l}0.00 \\
(0 \%)\end{array}$ & $\begin{array}{c}0.07 \\
(100 \%)\end{array}$ & $\begin{array}{c}0.07 \\
(100 \%)\end{array}$ \\
\hline & $\begin{array}{l}\text { Using Other } \\
\text { Country } \\
\text { Coefficients }\end{array}$ & & \\
\hline & Endowments & Coefficients & Total Gap \\
\hline Aust/Japan & $\begin{array}{c}0.05 \\
(20 \%)\end{array}$ & $\begin{array}{c}0.20 \\
(80 \%)\end{array}$ & $\begin{array}{c}0.25 \\
(100 \%)\end{array}$ \\
\hline Aust/ Britain & $\begin{array}{c}0.08 \\
(100 \%)\end{array}$ & $\begin{array}{l}0.00 \\
(0 \%)\end{array}$ & $\begin{array}{c}0.08 \\
(100 \%)\end{array}$ \\
\hline Aust/France & $\begin{array}{c}-0.02 \\
(-29 \%)\end{array}$ & $\begin{array}{c}0.09 \\
(129 \%)\end{array}$ & $\begin{array}{c}0.07 \\
(100 \%)\end{array}$ \\
\hline
\end{tabular}

\section{Conclusions}

This paper presents the results of a cross country comparison of the gender pay gap in four countries, Australia, France, Japan and Britain. We find that the countries with the most decentralised and uncoordinated wage bargaining systems (according to the OECD), Australia and Britain, had the smallest gender wage gap in the 1990s. While the gender wage gap did not change substantially for those working full-time over the 1990s in Australia, France and Britain, there has been a decline in its size in Japan. Kawaguchi's (2004) results suggest that the shift away from a seniority-based pay structure to one more closely linked to results has benefited Japanese women compared with men.

The seminal papers of Gregory and his co-authors argue that country-specific institutions were very important in explaining the relative size of the gender wage gap between countries. The results presented here support this conclusion. The relative gender wage 
gap between countries cannot be explained by human capital endowments alone. The major source of differences in the gender wage gap is still the rewards for these endowments. This suggests that the shift away from a centralised system of wage determination to a more decentralised system has not disadvantaged Australian women working 30 or more hours per week at least in comparison with outcomes in the three other countries in this study. Similarly, the substantial deregulation and decentralisation in Britain does not appear to have disadvantaged British women. These results hold for our two sets of estimates, those based on OLS regressions and those that take workplace fixed effects into account. We have however focussed on a limited group of female workers, those working full-time, and results may differ if part-time workers were included.

A significant innovation of the studies by Gregory and his co-authors was to examine labour market changes in a cross-country context. By comparing the gender wage gap between countries, it is possible to reach conclusions about the importance of national institutions in determining outcomes. International comparisons still offer the opportunity for increasing our understanding of how labour markets work. Cross-country comparisons continue to provide interesting and relevant material for those studying the gender wage gap.

\section{References}

Altonji, J. and Blank, R. (1999) 'Race and Gender in the Labor Market', in ed. Ashenfelter, O. and Card, D. Handbook of Labor Economics, Elsevier Science.B.V. Amsterdam.

Australian Economic Review, (1999) Policy Forum: The Equal Pay Case - Thirty Years On, vol. 32, no. 3 pp265-297.

Becker, G. (1975) Human Capital, $2^{\text {nd }}$ ed. University of Chicago Press, Chicago.

Blau, F. and Kahn, L. (1997) 'Swimming upstream: Trends in the Gender Wage Gap Differential in the 1980s', Journal of Labor Economics, vol. 15, no. 1 pp1-42.

Card, D. Blundell, R. and Freeman, R. (2004) 'Introduction' in Seeking a Premier Economy by David Card, Richard Blundell and Richard Freeman (editors). NBER, Chicago USA

Deaton, A. 1998. The Analysis of Household Surveys. A Microeconometric Approach to Development Policy. World Bank. John Hopkins University Press, Baltimore.

Department of Trade and Industry (1999) Workplace Employee Relations Survey: Cross-Section, 1998 (computer file). $4^{\text {th }}$ ed. Colchester: The Data Archive (distributor), 22 December 1999. SN: 3955. 
Grainger, H. and Holt, H. (2005) Trade Union Membership 2004 Department of Trade and Industry, UK. April.

Gosling, A. and Lemieux, T. (2004) 'Labour Market Reforms and Changes in Wage Inequality' in Seeking a Premier Economy by David Card, Richard Blundell and Richard Freeman (editors). NBER, Chicago USA

Gregory, R.G., Anstie, R., Daly A. and Ho V. (1989) ‘Women’s Pay in Australia, Great Britain, and the United States: The Role of Laws, Regulations and Human Capital', in eds. Michael, R.T., Hartmann, H.I. and O’Farrell, B, Pay Equity Empirical Enquiries, National Academy Press, Washington.

Gregory, R.G., Daly A. and Ho V. (1986) 'A Tale of Two Countries: Equal Pay for Women in Australia and Britain', Discussion Paper no. 147, Centre for Economic Policy Research, Australian National University, Canberra.

Gregory , R.G. and Duncan, R.C. (1981) 'Segmented Labour Market Theories and the Australian Experience of Equal Pay for Women', Journal of Post Keynesian Economics vol. 3, 403-28.

Gregory, R.G. and Ho, V. (1985) 'Equal Pay and Comparable Worth: What can the US learn from the Australian experience?' Discussion Paper no. 123, Centre for Economic Policy Research, Australian National University, Canberra.

Gregory, R.G., and Daly A. (1991) 'Can economic theory explain why Australian women are paid so well relative to their United States counterparts?' in ed S. Willborn, Women's Wages: Stability and Change in Six Industrial Countries, International Review of Comparative Public Policy, vol. 3, JAI Press Inc. Greenwich, Connecticut.

Gregory, R.G. (1999) Labour Market Institutions and the Gender Pay Ratio, Australian Economic Review, vol. 32, no.3 pp272-8.

Kawaguchi, A. (2004) 'Changes in the Japanese Gender Wage Gap in the 1990s', paper presented to the 2004 Conference on Feminist Economics, Oxford, August.

Meng, X. and Meurs, D. (2004) 'The Gender Earnings Gap: effects of institutions and firms - a comparative study of French and Australian private firms', Oxford Economic Papers, vol. 56 pp189-208.

Mincer, J. (1974) Schooling, Experience and Earnings, NBER, New York.

Mumford, K. and Smith, P.N. 2004, "Job Tenure in Britain: Employee Characteristics versus Workplace Effects.” Economica. 71, 275-298.

Mumford, K.A. and Smith, Peter N. (2003) "The Gender Earnings Gap in Britain." IZA Discussion Paper 1109. 
Oaxaca, R. (1973) 'Male-Female Wage Differentials in Urban Labor Markets', International Economic Review, vol. 14, no. 3, pp693-709.

OECD (1997) Employment Outlook, OECD, Paris.

Ponthieux, S. and Meurs, D. (2005) ' Les Facteurs de l'écart des salaries entre homes et femmes ont-ils changé depuis 1990?’, INSEE- seminaire recherché du 21 Avril.

Whitehouse, G. (2001) 'Recent Trends in Pay Equity: Beyond aggregate statistics', Journal of Industrial Relations, vol. 43, no. 1 pp66-78.

Wooden, M. (2000) The Transformation of Australian Industrial Relations, The Federation Press, Sydney.

Wooden, M. (2001) ' Industrial Relations Reform in Australia: causes, consequences and prospects’, Australian Economic Review, Vol. 34, no. 3 pp243-62. 